\title{
短報 \\ 吉田尚*・山口昇一** : 北海道松前郡大千軒岳付近の中部石炭紀化石
}

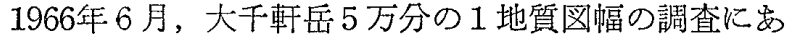
たつて，知内川支流住川流域の大千軒岳北東力約 $5 \mathrm{~km}$ 内外の数力所の地点で, 転石めるいは露頭の崩れから紡 鍾虫㐨よび珊瑚化石を採集した。

北海道大学湊正雄によつて，これらの化石が研究され た結果，つぎのと和り鑑定された.かつこ内は標本番号.

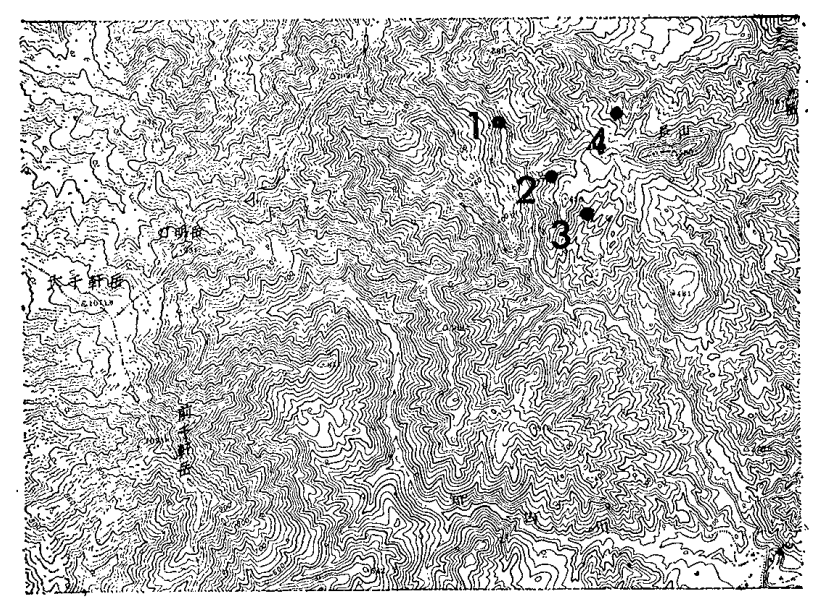

産地1. Carinthiaphyllum yezoense $\mathrm{sp}$. nov.（地 調大千軒岳 $66139=$ 北大 $18791 \cdot 18792 \cdot$ $18793 \cdot 18794 \cdot 18795)$

Chaetetes sp. (地調大千斬岳 66139 二北大 $18798 \cdot 18799)$

Fusulinella? sp.

2. Fusulinella sp.（地調大干軒岳 66278)

3. Chaetetes sp. (北大 18813 (1) （9)

Fusulinella? sp.

4. Chaetetes sp.（地調大千軒岳 66284）

Fusulinella? sp.

これらの化石は中部石炭紀の時代を示すもので，この

* 地質調查所地質部

** 地質調查所北海道支所

地質学雑誌 第73䄅 5 号 260 第
産地は湊・国府谷（1961）によつて報告された上ノ国村 大平山付近のFusulinella の産地とは約 $20 \mathrm{~km}$ 離れて いる。

化石をふくさ転石は採集地付近に分布与る礫状石灰岩 あるいは石灰質砅岩に由来するるのである，この層は石 灰岩礫するいは礫状・角礫状ないし不規則形の石灭質部 が，泥質・石灭質・凝灭質物質によつてかためられたもの である。礫女るい礫状部は石灰岩の注が, 赤色・緑 色のシャールスタインや赤色・灰白色のチャートからな り，後者などが多くなると赤色石灰質礫岩に移過する。 䃯もるいは䃯状部の大きさは最大 $30 \mathrm{~cm}$ 径, おおくは 0.5〜 $3 \mathrm{~cm}$ 径である. 礫状石灰岩めるいは石灰質礫岩は 愿さ数 $10 \mathrm{~cm}$ 15mのレンズ状岩体で, 連続性にとぼし く, 住川一带の古生層のなかに数枚はさまれている.こ の付近の古生層はこのほか, 赤色・灰白色テャート, 赤 色・渌色のシャールスタイン, 粘板岩, 赤色礫質砂岩, 带黄色・白色石灰岩薄層加らな。砂質砂岩はその層準 近くに発達する赤色のシャールスタイン・チャートの細 礫ないしより細粒の砕展物からなり，礫状石灰岩ととも に同時堆積的なものと考えられる．住川一带の中部石炭 系は，上にのべたように赤色を呈するシャールスタイン とテャートが発達し, 江差町・上ノ国村・松前町・福島 町にかけて分布するいわゆる古生層のなかで，特徴的な 岩相を示す. 住川一帯・大平山にか惊ての中部石炭系と ほかの地域に広く分布するいわゆる古生層との関係はな だ明らかではない。

化石を鑑定し，いろいるとご教示いただいた湊正雄教 授に深く感謝する。

\section{文献}

湊正雄・国府谷盛明（1961），北海道懀山郡上ノ国村の Fusulinella. 地質雑, vol. 69, p. 161. 